\title{
Geological Aspects of the Channel Tunnel Scheme.
}

\section{By John Pringle.}

$\mathrm{T}$ HE numerous advantages that will result from the making of a tunnel between England and France have long been recognised; but it may not be generally known that in support of such a scheme legislation dealing with the preliminary procedure passed both the French and British Parliaments so long ago as 1875 . Less than five years later a start was actually made and headings were commenced on both sides of the Channel, but the failure of the French Channel Company, followed by an order issued by the British Government to close down the work of the British engineers, brought the

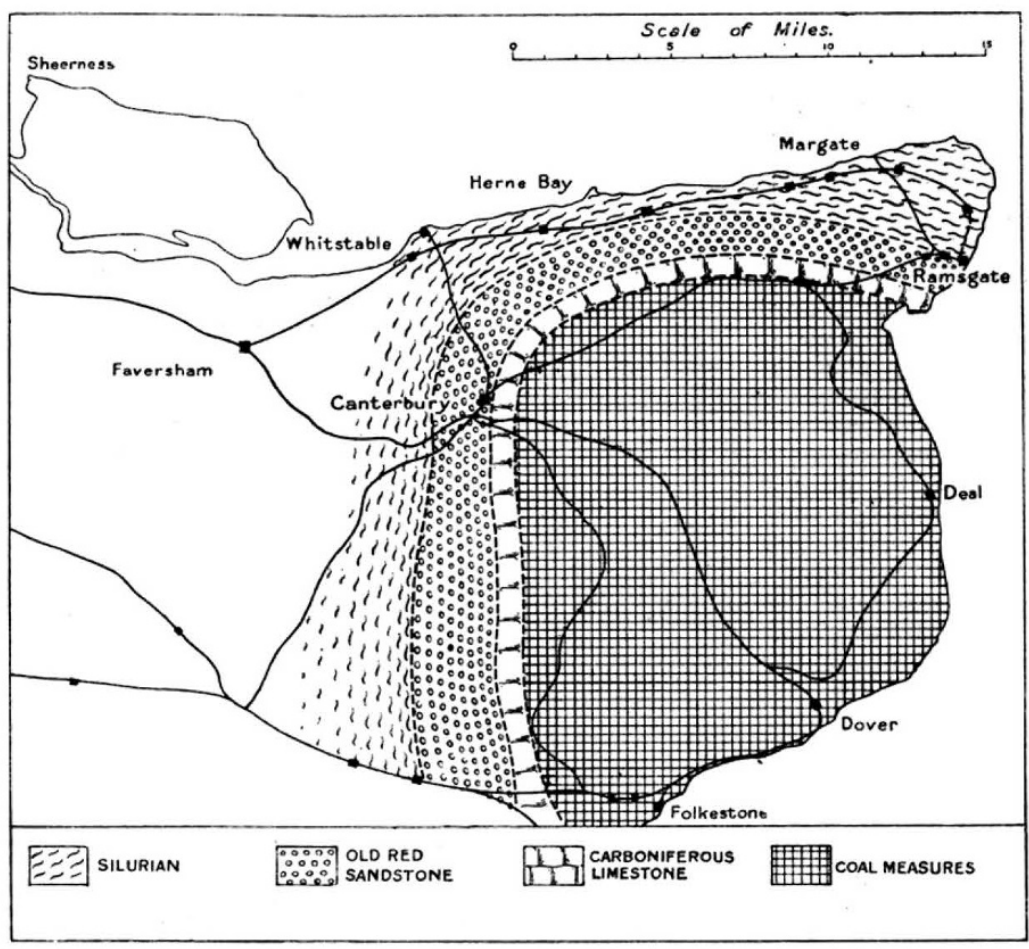

Fic. 1.-Sketch map of the Palæozoic strata proved at depths varying from $900 \mathrm{ft}$. to $1400 \mathrm{ft}$.

does it seem needful to do more than merely mention that the theories advanced in 1855 by Godwin-Austen, in a remarkable paper "On the Possible Extension of the Coal Measures beneath the South-Eastern part of England," gave rise to considerable interest in the problems connected with deep-seated geological structures. It is sufficient to say that most geologists were so certain of the occurrence of Coal Measures under Kent that Prestwich in 1873 maintained that these old rocks would be found sufficiently near the surface at Dover to allow submarine tunnelling. Picturesque accounts of the excavations of a tunnel by working the coal made their way into the columns of the newspapers. When the boring made alongside the Channel Tunnel shaft at Shakespeare Cliff proved the presence of Upper Carboniferous Rocks with seams of coal, a great impetus was given to further exploration by the boring-tool, and since 1886 more than forty borings and shafts have been carried down to the Palæozoic rocks in East Kent.

The information obtained by many of the companies carrying out these explorations was, however, jealously guarded for commercial reasons, and had it not been necessary to seek the advice of geologists, perhaps few details of the borings would have become public knowledge. Fortunately, the advice of the officials of the Geological Survey was sought, and they were permitted to examine the cores of nearly all the boreholes. The excellent use made of these opportunities resulted, when publication was allowed, in contributions to geo-

project to a standstill. Now that the scheme has been revived it is hoped that the undertaking will be pushed through to a successful issue. Geologists agree that the excavation of the tunnel is practicable, and no obstacles which will defeat the ingenuity of engineers are likely to arise in the course of its construction.

During the years that have elapsed since the heading was stopped at Dover, much has been learned concerning the deep-seated geology of East Kent and of the opposite shore of France; and some of the results obtained may not be without interest at the present juncture.

It seems scarcely necessary here to relate the views held by early geological observers concerning the physical identity of the coalfields of Somerset with those of the north of France, and the continuity of the higher formations in both countries; nor logical science of the highest value. These borings have demonstrated that Kent, instead of being an area of simple geological structure, as was thought, is one of considerable complexity, and more geological formations have been proved underground in that county than in any other in England.

As an outcome of the work of the Geological Survey, it is now possible to map the Palæozoic platform, and to show the area occupied by the Silurian, Old Red Sandstone, and Carboniferous rocks (Fig. 1). Further, a plan ean also be made of the disposition of the Jurassic rocks on the Palæozoic floor and the general arrangement they would present, if all the strata down to the base of the Wealden were removed (Fig. 2). Fig. 2 is based on that published by the Geological Survey, but certain modifications of the outcrops of the

No. 3103, VoL. 123] 
formations have been made by me to incorporate later information. All of these formations are buried beneath a great thickness of Cretaceous and Tertiary deposits, some of which are depicted on Fig. 3, and the great anticline of the Weald has been shown to be a purely superficial structure superimposed on an underlying syncline.

In Northern France borings have also been made since the heading was driven at Sangatte near Blanc Nez. Here the Cretaceous rocks are nearly identical with those of Kent, but the Wealden anticline, which is prolonged into France, has been denuded down nearly to the oldest Jurassic strata. These occupy the low-lying tract known as the Boulonnais, and they are surrounded by chalk hills. In places, inside the ring of chalk, Palæozoic rocks are exposed at the surface, and this fact gave rise to the idea that a Channel tunnel might be excavated throughout in the older strata. At Dover, however, the discovery of Coal Measures at the depth of $1158 \mathrm{ft}$. below Ordnance Datum showed such a scheme to be impracticable, quite apart from other difficulties arising from the heavily watered Hastings Sands and Inferior Oolite.

The most important formations to be considered in the making of this tunnel are the Gault and the Lower Chalk. The lithological similarity of these rock-groups as exposed in the cliffs of Kent and in the bold headland of Blanc $\mathrm{Nez}$ is so close as to make it certain that no important change in mineral characters takes place in the beds immediately underlying the floor of the Channel. For example, the thickness of the Lower Chalk remains practically constant : in Kent it is 193 ft., at Blanc Nez, $189 \mathrm{ft}$." The work on the Channel Tunnel can thus be carried out with the advantage that identical strata are to be penetrated at each end.

The chief and, one might say, the only engineering difficulty likely to be encountered in constructing a tunnel in the Chalk would arise from the presence of water, and regarding the question of the amount and distribution of water in this formation many useful data have been obtained from the borings, shafts, and other works made in Kent and in northern France during the past forty years. The knowledge may be summarised as follows: in the Upper Chalk there is a great amount of water, in the Middle Chalk and perhaps in the higher part of the Lower Chalk there is a smaller quantity, but in the remaining portion of this lowest sub- division, the Grey Chalk and Chalk Marl of older writers, except in fissures, little or no water is found, in consequence of the increased amount of argillaceous sediment in this part of the series. Thus, the lower part of the Lower Chalk, which has generally been considered the most advantageous position in which to drive the tunnel, is favoured by all recent experience as the driest and most homogeneous part of the Chalk for this purpose.

At the same time, the relative dryness of the Lower Chalk does not preclude the possibility of meeting water in some quantity in that subdivision. The Chalk, like most other formations, has been subjected to pressure and folding, giving rise to

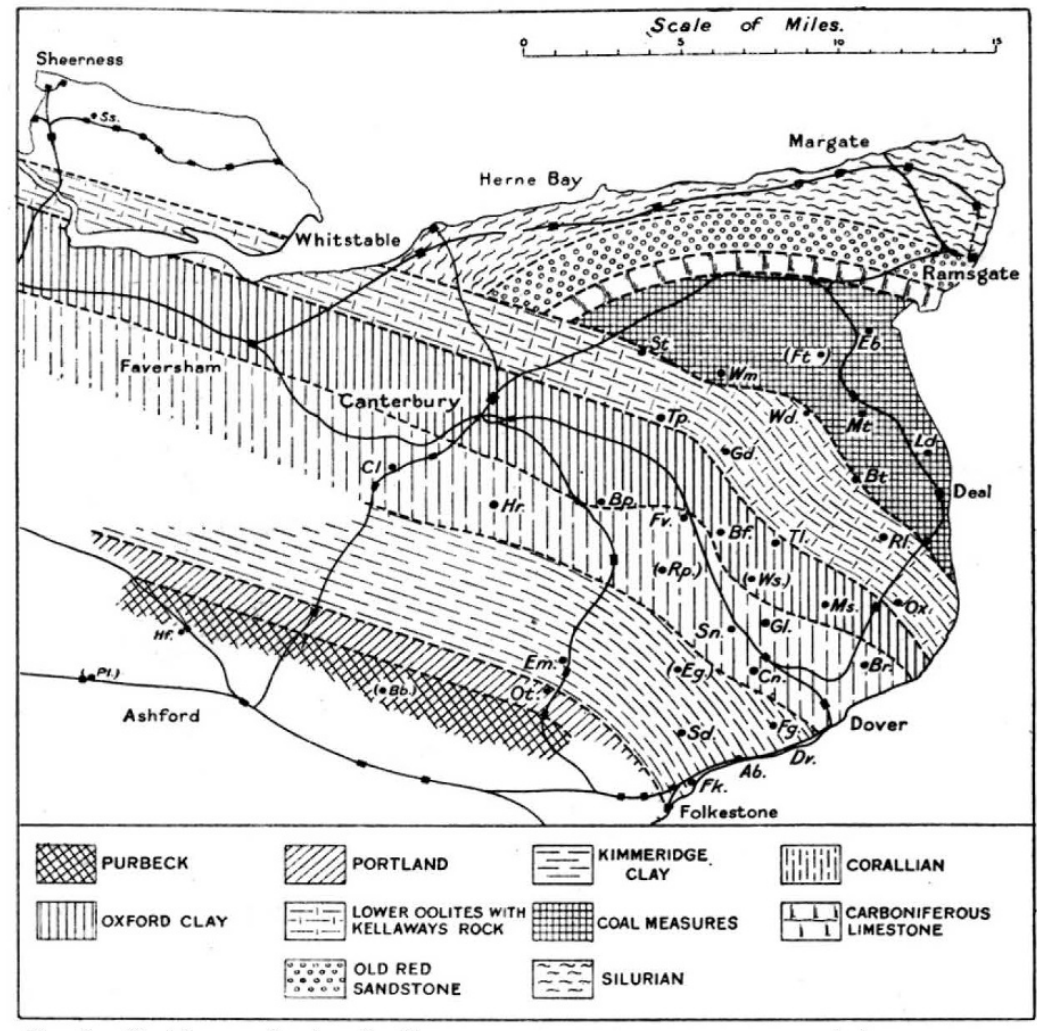

showing the disposition of the Jurassic strata on
East Kent. Boring sites shown thus: Dv., etc.

No. 3103, VoL. 123]

faults and fissures. These have a west-northwesterly trend in Kent, and a similar direction has been noted in France. They allow the passage of a considerable volume of water, even in the Lower Chalk. Thus, for example, a strong spring is given off from a fissure in the Lower Chalk at Lydden Spout, west of Shakespeare Cliff.

Obviously, therefore, much will depend on the relation of the tunnel to the trend of the fissures. Where the headings run parallel with the fissures little or no water need be expected. This was clearly demonstrated by the experience gained in driving the headings at Dover and at Sangatte on the French side of the Channel. At Dover a heading $7 \mathrm{ft}$. in diameter was driven for a distance of more than 2000 yards, in a direction approxi- 
mately parallel to the lines of faults and fissures. A small amount of sea-water made its way into the workings, but a hand-pump was found sufficient for dealing with the flow; the water caused no inconvenience, and was easily kept out by a ring of tubing. After an interval of nearly thirty years the heading was reported to be dry in 1912. On the French side, however, the engineers experienced much trouble in dealing with the water coming from a fault in the lower part of the shaft, and in a length of the heading driven nearly at right angles to the fissures a fair amount of water was also tapped.

The excavation of the lower part of the Lower Chalk is therefore not likely to be entirely free from water-troubles. The difficulties, in fact, may be increased if the original plans for the drainage of the tunnel are car. ried out. It may be remembered that it was proposed to drive a heading with an inclination of 1 in 80 down-hill from the shore at each side for a distance of two miles, and then to continue the excavations with a rising gradient of about 1 in 2000 to the centre of the Channel. This would probably mean that part of the tunnel situated under

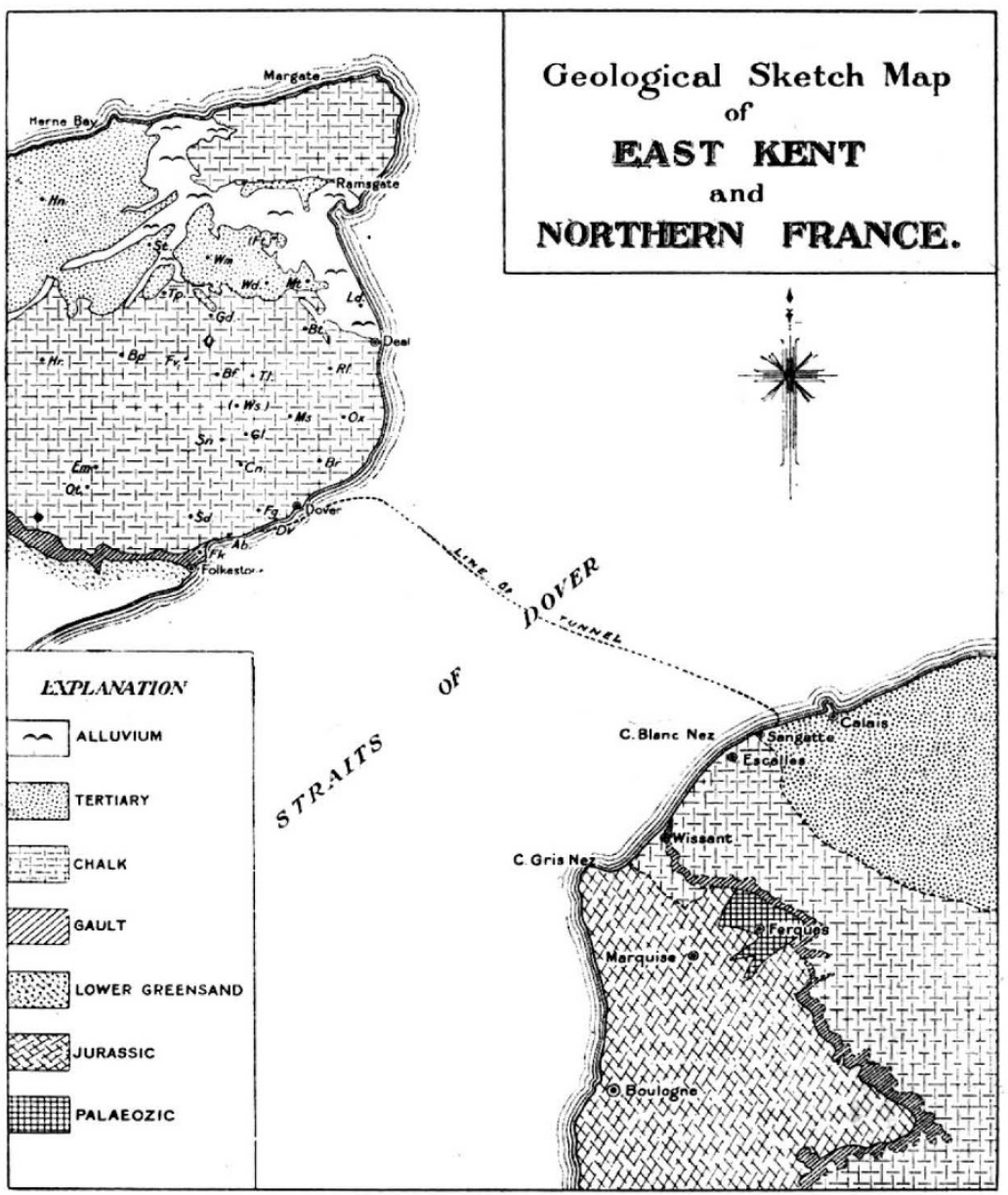

FIG. 3.
It is probable that in earlier discussions the Gault formation was given less consideration in the belief that it was overlain by water-bearing Upper Greensand; in fact the majority of existing plans show a narrow stippled band between the Gault and the Lower Chalk to represent a supposed outcrop of Upper Greensand. Now it has been clearly shown as a result of palæontological investigation that the clay-beds IX to XIII of later classifications of the Gault at Folkestone, and their equivalents at the south end of Blanc $\mathrm{Nez}$, represent in argillaceous facies the sandy beds of the Upper Greensand of the west of England. Consequently, if the headings at Dover and Blanc Nez were to be driven in the Gault at about the horizon of Bed IX, the workings would lie in a rgillaceous beds, and the risk of meeting a considerable volume of water would in this way be greatly reduced.

As a final remark, it may be suggested $\mathrm{th}$ a t pre cautionary $\mathrm{m}$ e a s u res should be taken by the e $n g$ i $n$ e e r s against the possibility of meeting drift. infilled valleys in the Chalk underneat $h$ the Straits of Dover. The geological chart showing the outcrops of the subdivisions of the Cretaceous rocks lie within the Middle Chalk, and would, therefore, cross the fissures at a rather low angle in strata known to allow the passage of water in increased quantities. This difficulty might perhaps be overcome by driving the tunnel at each end into a lower geological formation, namely, the Gault Clay. This is a point worthy of serious consideration by the engineers. If this plan were followed, the highest point at the centre of the tunnel would probably lie within the drier Lower Chalk. on the floor of the Channel, which was made by MM. Potier and A. de Lapparent as a result of more than 7000 soundings, certainly does not reveal any trace of former valleys in this region, nor has any recent evidence of their existence been obtained; but the fact that many such infilled valleys in the eastern counties of England have been shown to reach depths of more than 300 feet below Ordnance Datum emphasises the need for caution, since such a valley would probably carry a considerable body of water. 